\title{
Source Criticism or Dilettanti? Some thoughts on "Scandinavia's Oldest House" in Tingby near Kalmar, Småland
}

\author{
Lars G. Johansson
}

\begin{abstract}
In a number of articles the so-called Tingby House is presented as a feature from the Boreal Period, a sensationally early date for so distinct a house remnant. This article questions the dating and, more particularly, the way in which it was obtained. Inadequate source criticism ${ }^{*}$, improper use of ${ }^{14} \mathrm{C}$ dating and the lack of rigorous presentation of evidence in the argument itself means that both the date and the excavators' method must be regarded with considerable skepticism. The probability that the Tingby settlement is a multi-component site is supported by the ${ }^{14} \mathrm{C}$ date from 9 millennia, among other evidence, but is explained away in a methodologically unacceptable way by the excavators. The following article is thus a purely methodological comment, not a contribution to the Mesolithic debate.
\end{abstract}

Lars G. Johamsson. UV-Väst, Box 10259, S-434 23 Kungsbacka, Sweden.

During the 17th century an association was established in Italy whose name - Dilettanti has come to have a negative ring and connote incompetence or amateurism. Today's interpretation of the word, however, is a corruption of the original meaning. The association Dilettanti, i.e., the amateurs, the layman archaeologists, could best be compared with our day's local district associations (swedish: hembygdsföreningar). Most would probably agree with me that these form an extremely positive and important feature in today's society. It was thus not without hesitation that I set about writing the exposé which eventually was published in 'Populär arkeologi' no. 2, 1989. For without doubt things are happening at Kalmar District Museum: over several years they have greatly expanded the knowledge of the stone age in the Kalmar areal over that of previous generations. From the perspective of the media, they have taken ideal advantage of possibilities for whetting the interest of the National Audit Bureau (among others) in Swedish Archaeology. The excavators of the settlement at Tingby in Dörby Parish, Kalmar District, have thus contributed to their district.

But as in the case of the association "Dilettanti", these interests - i.e. those which appear from a local historical, not to mention local political, viewpoint to be important and correct - can easily conflict with the demands of a strict scientific treatment of the archaeological source material. If one has a find that at first glance appears unique, it is marketed so vigorously that there is no longer a place for scientific considerations. I raised criticisms from a scientific point of view in a letter to Westergren, inviting him to a debate in

\footnotetext{
* Translator's note: The term "source critisism" has been used here to translate the Swedish term "källkritik", which is not easily rendered into English. The Swedish term denotes a rigorous cvaluation of all sources of archaeological knowledge, including features, artifacts. spatial relationships, site formation processes and the logic of archaleological argument. The English phrase used should be read in this sense.
} 
'Populär arkeologi' on criticism, i.e. on the authority of sources of archaeological evidence and the rigor of archaeological argument. Instead the excavators stopped the article I submitted to no. 1, 1989 without a word to me. When my article was published in no. 2 , they replied with a rebuttal which didn't address the critique of their archaeological evidence and interpretive rigor, but was only grounded in criticism such as these: my critique was not timely, I hadn't been at the site (and thus was not among the enlightened), my comparisons with finds of houses in Halland "is hardly relevant (Rajala \& Westergren 1989:33)", etc. They don't bother to explain why one should need to pay a visit to the excavation in order to understand the implication of what Westergren has written or why comparisons with other source material aren't appropriate. The debate on source criticism whith I had sought deteriorated into mere polemic.

In their most recently published article in the subject the lopsided debate over the putative date of the site continues; there is still no critical approach to the sources of their evidence. "Any attempt at dating the house must be from the find distribution (Rajala \& Westergren 1990:27)" they maintain, and din't waste a word in the core of the criticism namely that the artifacts and the house cannot be associated in the way the excavators have associated them. Since a two-sided discussion of the controversy over the dating of the house itself apparently cannot be carried on - and to my knowledge no one has called into question the stone age origin of the lithic material from Tingby - I must satisfy myself with clarifying and completing the critique of their treatment of the source material that I presented in 'Populär arkeologi'. However, since the article was furnished with a different and misleading title, the references were taken away and the original appeared in Swedish, it may be appropriate to first present the original article in its entirety:

\section{STONE AGE SETTLEMENTS: THE EXAMPLE OF TINGBY}

In a number of primarily popular articles Ebbe Westergren of the Kalmar District Museum described a house find in Tingby, a few kilometers outside of Kalmar, as "Scandinavia's Oldest House" (Westergren \& Hansson 1987; Westergren 1988a, 1988b, 1988c and 1988d). This interpretation was also presented at a seminar held at Riksantikvarieämbetets (The Central Board of National Antiquities) office in Kungsbacka in October, 1988. The quotations in what follows are from the articles listed above!

The remains of houses from the Stone Age in general are, as Westergren quite correctly indicates, relatively uncommon. Houses from the Mesolithic are at least as rare. But the question remains whether the house at Tingby really is from the Stone Age. I believe that there are strong grounds for doubt. In this article I intend to analyze the argument the excavators put forward on this question, and also present several examples of house finds from Halland which may be instructive in this context.

The problem shared by houses, postholes, hearths, etc. is that they are extraordinarily complicated as sources of archaeological evidence. I take the Tingby house as my starting place because of serious critical deficiencies in the evaluation of the complex evidence in this case, not because the find itself differs or is separated in any way from the general problems shared by such features.

The settlement site at Tingby was discovered in 1986 in conjunction with construction of a pipeline. The house under discussion was found during excavation in 1987 and 1988, in addition to tools and debitage of flint and porphyry. What dates were presented, then, from the Tingby occupation? The artifacts flint tools - were said generally "based on parallels in Scania and on the west coast to date ca. $6000-6500$ b.c. (calibrated timescale).

This applies only to the original article (Johansson 1989). 
Two ${ }^{14} \mathrm{C}$ dates support this dating". Which parallels were referred to was not mentioned. Whence the material for the ${ }^{14} \mathrm{C}$ date was taken, or what actually was dated we may unfortunately never know, nor are the actual chronometric values given, which is remarkable for a find as sensationally early as Westergren claims. Even if it is "only" in the context of popular articles, they are the only ones that exist.

Are there other dates which are not given? The incomplete treatment of these questions seriously weakens the excavators' argument.

But which of these dates the house in the Mesolithic? From what I can see presented, none. Even if we accept the date of the lithic material, it is obvious that it is these that are used to place the house temporally! Note also that no plans are provided; this would have at least given the reader the opportunity to make typological comparisons with other house finds, although of course Mesolithic houses are scarce.

The only really strong argument for the house dating to the Stone Age is thus a postulated spatial connection between the house and the lithic material, of which $80 \%$ was found inside the house walls. Doesn't it appear astonishing that the settlement's inhabitants, who so carefully cleared stone from the place the house was built, would then fill it up with large quantities of sharp-edged lithic debitage? What marvellous logic did these people employ, sitting and knapping flint where they slept, when people in a mild climate would be able to carry out this untidy task in another location and avoid lying in chips of stone. For, as Westergren writes, "people naturally want the place they live to be as level and free of stones as possible". It goes without saying this is curious, and the excavators' own argument actually becomes a good reason to adopt the position that the house and lithic material are not contemporary. Let us posit that a group of people during the Iron Age decide to build a house at Tingby. The thousands of years which have passed since the spot was occupied by Mesolithic hunters and fishers have hidden their traces; only the large stones stick up from the ground. The people remove these, build their house and begin to cultivate the surrounding land. The Mesolithic layer is greatly disturbed through these activities; only under the floor of the house itself is the earlier cultural layer preserved intact. Westergren writes: "Inside the house a sheet midden of up to $12 \mathrm{~cm}$ deep was found. Outside only scattered, thin patches of this layer were visible." This quote certainly does not support his hypothesis of contemporaneity.

For the same reasons, the argument that artifacts from the Stone Age in postholes give usable dates crumbles. When people dug holes for house posts during the Iron Age, of course they went through the old cultural layer, and artifacts from it easily fell down in the newly dug holes. When the posts were raised, the people refilled the rest of the hole to support the post. What happens in this case does not need to be explained further; it's clearly illustrated in the popularly written Danish volume "Arkaeologisk håndbog" (Archaeological Handbook) under the heading "stolpehul" (postholes). The remarkable axe which Westergren believes "probably was an offering, maybe at a consecration ceremony when the house was completed" in reality has fallen in a hole dug when the Iron Age people set in their own house posts several thousand years after the Mesolithic settlement.

From the view point of source criticism, postholes are very hard to use for dating; this is pointed out even in much of the older literature (e.g. Hatt 1957), but for the sake of clarity I will return to this shortly with some recent examples from Halland.

Beyond this argument the excavators present only a negative argument in favor of their interpretation: "No later settlement has disturbed the picture" they claim, but such an assertion is, of course, very hard to demonstrate. One can state with equal or even greater certainty that the house itself constitutes evidence to the contrary. According to my interpretation one can question the scholarliness of asserting the occurrence of a phenom- 
enon (or date) on the basis of what we cannot observe (or date). This problem returns now and then in the archaeological literature; I will not, however, go into this more or less philosophical question of method here, but prefer to deal with the immediate argument for or against a particular interpretation.

In my view, then, the spatial connection between the lithic material and the house can be removed from the debate. A certain such connection is found, however, between the house and the hearth, situated at the one short end of the house, "built of small stones ca. 5 $\mathrm{cm}$ above the floor". A date for this hearth could provide, if not proof, at least a probable estimation of the house's actual age. But since the connection isn't totally demonstrable here either, a differing analytical result would naturally be hard to accept and easily dismissed as the result of contamination. Nevertheless, we can expect an attempt at dating the hearth and the publication of the results. A later hearth would, of course, independently of any demonstrated connection between the house and hearth, refute the negative evidence mentioned above.

The question of whether it is valuable to treat the oldest, most unusual, unique or sensational as most important must be separated from discussion of the age of the house. Archaeology is, after all, a generalizing discipline, where the universally applicable normally should attract the most attention. The race for the world's oldest, largest, strangest is certainly marketable to the mass media, and may even allow itself to be marketed to institutions and foundations, but should hardly be allowed to inform scientific argument. The material from Tingby is, certainly, interesting enough in itself, and even without the house an exciting find, when we remember how little has been known about the Stone Age in the area of Kalmar. But it is scarcely this state of affairs which has led to the desire to create a Stone Age Center in Tingby. One has the impression that it is the unique house, "Scandinavia's oldest" which gives the place its singular status.

\section{HOUSE FINDS IN THE DISTRICT OF} HALLAND

I now intend to turn my attention to a few prehistoric house finds in Halland. Those which are of most immediate interest are Båtsberg, some kilometers east of Varberg, Nydala, outside of Halmstad, and Sannagård, near Falkenberg. The settlements were found during the survey that the national board office in Kungsbacka conducted prior to construction of a natural gas pipeline between Malmö and Göteborg. All have been investigated by the same office, and the latter two were published in 1989 (Artelius \& Lundqvist 1989).

At Bătsberg, surface finds suggested a Stone Age site. During excavation in 1985 a longhouse and remnants of hearths and refuse pits were recorded (Fig. 1). Lithics and small amounts of pottery were found in the pits and the hearths, unequivocally belonging to the Early Neolithic Funnel Beaker culture. No traces of later occupation were observed, i.e. all artifactual material found originated from the Neolithic settlement. Early Neolithic houses are known in Scania and Denmark as well, so the interpretation didn't seem to be unreasonable. Three ${ }^{14} \mathrm{C}$ dates are currently available: Feature 343, a hearth containing Neolithic pottery, gave the interval 3900-3400 b.c., i.e. Early Neolithic. But features 261 and 521 (pits on the outer edge and outside of the house, respectively) gave ${ }^{14} \mathrm{C}$ dates of 760 140 b.c. and A.D. $655-1010$ respectively! The date of the hearth must be considered to give a stronger indication than the other results, even if we cannot assert that the house is dated in a completely satisfactory way. In Nydala, during test excavations, several hearths were found, one of which contained burnt bone and pottery. Since the area in the immediate vicinity is today dotted with tumuli several have been investigated and dated to the Bronze Age - it was plausible to see it as remains of a plowed-up tumulus or of activities connected to interment. Sure enough, a ${ }^{1+} \mathrm{C}$ sample dated to the Bronze Age/Pre-Roman Iron Age (the interval 520-395 b.c.). 


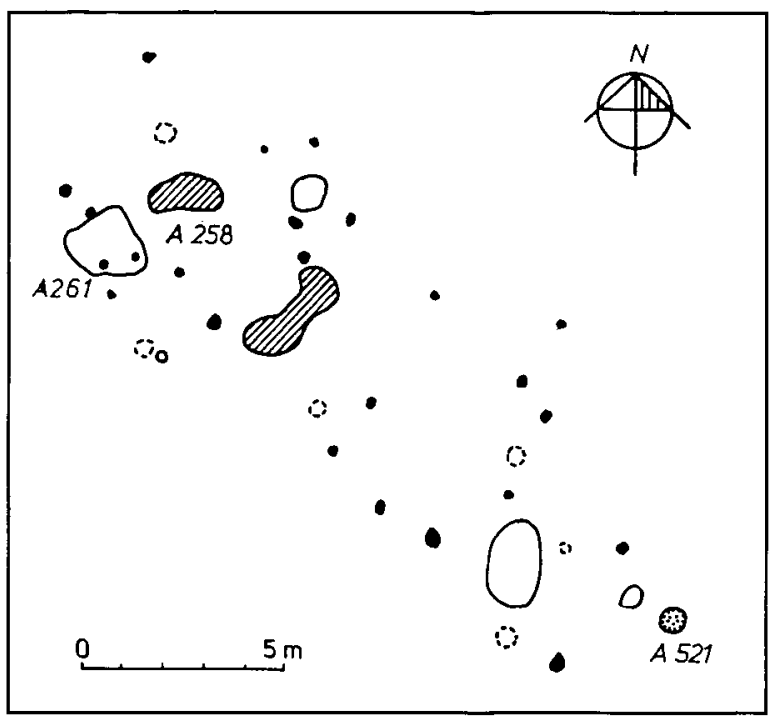

Hearth

$O$ Pit

- Posthole

$\therefore$ Posthole, uncertain

(1) Cooking pit
Fig. I. The Batsberg House possibly from the Early Neolithic. Drawing by E. CraafordJonsäter.
During the summer of 1985 , a large surface was cleared, and a little less than a meter from our test trench a lovely longhouse, slightly oval in form, was found (Fig.2). Plenty of construction details could be documented, including that a number of the walls had burned and fallen into the house; the remains of the wattle and daub gave a good picture of how the house had looked. Not even one artifact was found; the hypotheses that the house was connected with the dated hearth, which lay directly outside the house, first crumbled when
${ }^{14} \mathrm{C}$ samples from the burnt walls, postholes and pits (feature 121, feature 108, and feature 16) showed that the house was from the Roman Iron Age or immediately thereafter (the ${ }^{14} \mathrm{C}$ interval A.D. $\left.135-630\right)$. There is also evidence for this house type elsewhere during this period. In this case should the spatial data be given greater and the ${ }^{14} \mathrm{C}$ results lesser importance? Certainly no one would seriously maintain such a position.

In Sannagård remains of a house were excavated during the summer of 1986. In
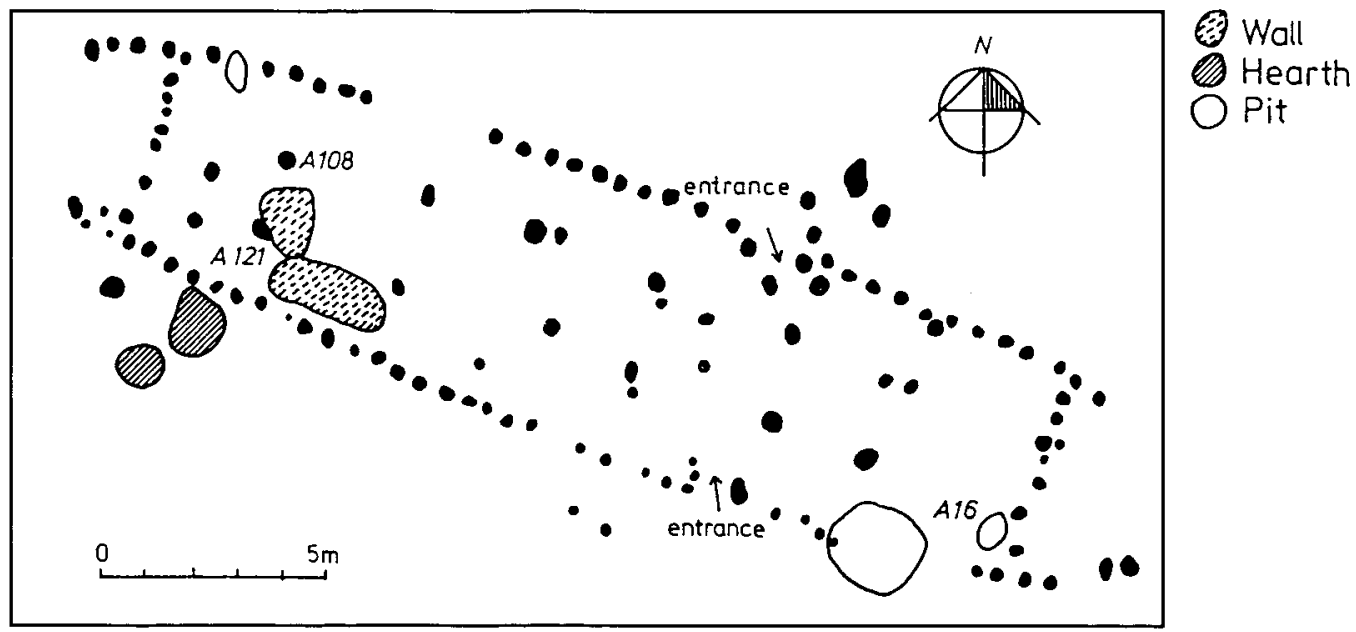

Fig. 2. The Nydala House, dating to Roman Iron Age. Drawing by E. Craaford-Jonsäter. 
order to test the chronological reliability of the postholes, four different postholes were dated. The result was four different dates, the earliest from the interval $195-70$ b.c., the latest from the interval A.D. 415-595. Either the house stood for nearly 800 years, which doesn't seem entirely likely, or material from other periods landed in the postholes, and it was this material which was dated. The dated charcoal from postholes has the same analytical value as the axe from the Tingby house.

The examples given show well enough on what shaky ground Westergren has built his sensational Mesolithic house. In the excitement over a new and really interesting find, as for example, the Stone Age settlement at Tingby, it is easy to disregard the critical inspection of the sourses of archaeological knowledge which must be the base of all archaeological research. The importance of such an inspection is made very clear in a rather recent publication where blanketed sites in the area of Göteborg were presented (Andersson et al. 1988). In very cautious terms, the authors point, among others, to the already published finds from the classic site at Sandarna (Alin et al. 1934) as possible house remains. If this interpretation is correct - and their framing of the question of any interest - these house finds would probably be among the oldest - at least in Sweden.

\section{OUTLINE OF THE CRITIQUE}

This concludes the original article. The main points of my criticism can be summarized as follows:

- An unequivocal spatial connection can only exist in a sealed context. Tingby as a whole is an accumulated deposit (Moberg 1969:50f).

-Artifact material of different character and from different time periods often occur together on the same site. In the case of Tingby, no proper critical inspection of this possibility in terms of the sources of the archaeological data was undertaken.
- Remains of a house with associated postholes, door openings, hearths and any other related architectural elements can be defined as a closed find. Thus, there should be a tight spatial association between these elements. The hearth should therefore have been dated since its value as a source of reliable data is high.

- Finds from postholes are, practically speaking, unusable for dating the construction of the posthole in question.

- Negative evidence should be used sparingly in archaeology.

- No plan or profile has been provided.

- No dates have been published.

All of the above points have their origin, of course, in what was then known from the 1987 and 1988 articles.

I have explained in some detail why one cannot argue from the spatial connection of artifacts (let me once more emphasize that no one doubts the Mesolithic date of the artifacts!!) and the remains of the house, and it would not provide anything new to broach the subject again. It seems remarkable that the excavators fell into such a trap, since as we have seen, houses from the Central Board's (and others') excavations, and the scientific scrutiny and critical discussion of archaeological sources these finds engendered and which I presented in the original article were to all appearances already known when the excavation at Tingby was begun. We investigate a number of houses from the Stone Age yearly, most recently on the island of Orust, where the same argument used by the excavators could be made; but raising further examples of why in reality this is not the case is probably not meaningsful since, as we' ve seen, comparisons of this sort were dismissed, without further comment, as irrelevant.

When, however, the excavators write in response to my article that "Johansson assumes in this contribution that the house was built during the Iron Age" (Rajala \& Westergren 1989:33), it is obvious that they have not 
grasped what I attempted to clarify at all. The phrase "let us posit that a group of people during the Iron Age decide to build..." implies a hypothetical relationship to the date in question, i.e., the variable "Iron Age" can be replaced with any other date desired. The example should thus serve to show that based on the arguments presented thus far in Westergren's articles dates other than that presented should also be conceivable, but should not be taken to uphold a specific date. In this context $I$ should emphasize that several ${ }^{14} \mathrm{C}$ results were unknown at the time the article was drafted. It's also very interesting to note the change from an assumption of an Iron Age date in my article (cf. the quote above) to a dedication to this dating in the excavators' latest work. Furthermore, the dating has been made based on criteria of house typologies: "It seems remarkable to, as Johansson has done, attribute the house to the iron age simply on the basis of its construction" (Rajala \& Westergren 1990:27). Besides the fact that all of this emotional argument against an Iron Age date for the house (including an article taken from the very local newspaper Ölandsbladet and written by a journalist (!) that was used to show the injustice of my criticism) misses the mark since I never advocated an Iron Age date, it became clear again that the excavators didn't understand the significance of my criticism: it is not about dating the house to the Mesolithic or Iron Age, or as far as that goes to any period, but about how, in general, the house is dated and on the basis of what aspects of source critisism. The assertion that I dated the house to the Iron Age based on typological or other attributs related to the construction of the house collapses, with that, under its own absurdity. As far as I am concerned it makes no difference what the date of the house actually is - it could readily be the Mesolithic but there must be a scientific examination of the validity of the argument made by the excavator. This is still lacking. In the latest article it is also evident that the Tingby site has undergone certain noteworthy changes since my previous article. For example, the excavators' assertion that the date of the house is not based on finds in the postholes is decidedly surprising. In their rebuttal from 1989 they already claimed this was a misunderstanding on my part (Rajala \& Westergren 1989:33). In the most recent publication they claim that "neither finds nor C- 14 specimens from the post-holes were used in the dating, since the post-holes contain scarcely any finds or pieces of charcoal" (Rajala \& Westergren 1990:26). One wonders what Westergren acually meant, when he wrote: "The most remarkable find was an axe which was tucked down against one of the posts in the south end of the house. This axe probably was an offering, maybe at a consecration ceremony when the house was completed" (Westergren $1988 \mathrm{c}: 26$; cf. also the original article). Misunderstanding or not, this cannot be interpreted in any other way than I have done it. Similarly one wonders over the metamorphosis which feature 60 apparently undergoes in the course of the article: only several rows below the assertion quoted above ("neither finds nor C14 specimens from the post-holes were used in the dating...") it is stated that the date was run on material from a posthole ("...he uses the $\mathrm{C}-14$ result from feature $60 \ldots$ in spite of the fact that the specimen was taken from a post-hole" (Rajala \& Westergren 1990:26)! Is it possible to decide whether the postholes at Tingby really are postholes or not? The excavators themselves seem to have doubts on the matter.

\section{ON DATING WITH ${ }^{14} \mathrm{C}$}

The criticisms presented here are, however, relatively trivial in this context. They become serious when the excavators address how the house actually has been dated. The hearth apparently has been radiocarbon dated. In the comment on my article they said: "We have had two ${ }^{14} \mathrm{C}$ samples analyzed from the hearth. Since the results differ from one another by ca. 2500 years, we naturally cannot use either of them for dating" (Rajala \& Westergren 1989:33). This remarkable state of affairs, in 
spite of "an open line in relation to our colleagues" (Rajala \& Westergren 1989:33) has not been mentioned at all in earlier articles or during Westergren's presentation in Kungsbacka. Even if anyone still wants to believe the house can be given the same date as the lithic material - according to the excavators, then, $6500-6000$ b.c. calibrated date, a divergence of 2500 years from this time period reasonably implies that something that did not originate in the Mesolithic must have been dated! The claim that "no later occupation has disturbed the picture" (Westergren 1988c:26) seems, therefore, not to accord with reality. Such a simple state of affairs would have been almost surprising at any other stratigraphically sealed sites. Unlike their earlier claims, the excavators confess that in fact the site is not undisturbed: "These particular specimens provide firm evidence that the charcoal has been affected by activities and/or disturbances during different periods" (Rajala \& Westergren 1990:26). As far as this goes, then, it is a step forward in the argument over archaeological authority and source criticism. The most notorious part of the argument, however, is the obviously seriously-meant statement that the dates that were obtained do not provide any information about the age of the house because they differ from each other! The same argument is repeated in the most recent article: "As far as the C14 analyses from the hearth - feature 59 - are concerned, there values differ by some 2000 years, and the problem is therefore which value should be chosen: the iron- or the neolithic stone age dating" (Rajala \& Westergren 1990:26).

What then, are the dates from Tingby? As stated earlier, for some reason the excavators have chosen not to publish any before now, despite the opportunity which the reply in 'Populär arkeologi' offered. The 12 analyses' that I have been able to find reveal an interest- ing spectrum of dates encompassing the period from 6570 b.c. to A.D. 880 . In short, every archaeologically defined period in between is represented! The dates can be divided into two main groups, however: those which are directly associated with the house and those which were taken from outside of it.

Four samples belong to the former group: Ua-696 and 697 from the hearth in the one short end of the house and Ua-698 from "sheet midden in what is here interpreted as a vestibule outside of the entrance" 3 , also Ua-726 "from a posthole which may be associated with the inner construction of the house"'. As is clear from the table below, none of the four provides a date corresponding to those given by the excavators. In the latter group of samples, which have no connection to the house, there are two samples, Ua-727 "from a presumed hearth immediately outside of the house" and Ua-728 "from a presumed posthole immediately outside of the house", which both date to the Mesolithic, obviously agreeing well with the excavators' date of the lithic material. It is obviously these two dates which the excavators assert support the Mesolithic date for the house.

Rather than entertaining the possibility that some of the dates from the former group (i.e., samples directly associated with the house, hearth and sheet midden) may correspond to the actual age of the house, they reject them completely and come up with their own date. Rather than searching for a secure spatial association, they base their date on a multicomponent find. Rather than considering the validity of alternative interpretations, they rush to deny, contradict and corrupt the crucial aspects of the problem. The excavators treatment of the ${ }^{14} \mathrm{C}$ results gives rise to several observations. Features 59, 30, 60, 90 and 102 are considered in a rather detailed discussion, where various explanations showing why

\footnotetext{
2 These dates were run at The Svedberg Laboratories, Uppsala. I want to thank Göran Possnerı who kindly placed the results of the analysis at my disposal. If other analysis have been run, I am unaware of them.

3 The quotation is taken from the excavators description to the ${ }^{14} \mathrm{C}$-laboratory. Translated from swedish for this article.
} 
certain samples gave "incorrect" dates are advanced. For example, of feature 59 they now say: "The hearth had also been disturbed, this could be seen by the furrow left by ploughing which ran straight through it". Of feature 30 they say: "It is not possible to link the charcoal fragments directly to the occupation layer". Of feature 60 they note "The possibility of later material having contaminated the specimen cannot be excluded", and so on (Rajala \& Westergren 1990:23). If we make the reasonable assumption that the excavators took their sample so that the risk of contamination was minimized, we must ask why all these samples were analyzed. Remarkably enough - as can be seen from the quotes above - none of these points was included in the description of the samples sent to the The Svedberg Laboratory that ran the dates. On the contrary they claim a relatively unequivocal spatial connec- tion with the architectural elements of the house: "The sample comes from the upper part of the hearth found inside the house at the one end" (feature 59); "The sample comes from the sheet midden in what is interpreted as vestibule outside of the entrance" (feature 30 ), etc (cf. the quote above). It is thus difficult to escape the conclusion that the excavators had a different assessment of the reliability of the samples in the field than they presented in the post hoc description given now!

Equally remarkable is that contamination can be ruled out only in those cases where the ${ }^{14} \mathrm{C}$ analysis gave "correct" results, such as, for example, feature 90 . Here, luckily enough, neither plows, forest fires, nor sea level transgressions have left there traces. The whole argument is thus ultimately based on the fact that the artifacts date the site - including the house - to 6500-5200 b.c. (earlier 6500-

\begin{tabular}{|c|c|c|c|c|}
\hline \multicolumn{5}{|c|}{${ }^{14} \mathrm{C}$-analyses from Ingby, Kalmar } \\
\hline Laboratory nr & Feature & $14 \mathrm{C}$-age $\mathrm{BP}$ & Cal BP & Cal BC(4) \\
\hline Va-696 & A 59 hearth & $1950 \pm 100$ & $2039-1920$ & $90-A D 130$ \\
\hline Ua-697 & A 59 hearth & $4190 \pm 100$ & $4863-4564$ & $2914-2615$ \\
\hline Va-698 & R 30 & $6520 \pm 140$ & $7499-7279$ & $5550-5330$ \\
\hline Ua-726 & $A 60$ & $1260 \pm 80$ & $1284-1070$ & $A D 666-880$ \\
\hline Ua-727 & A 90 & $7650 \pm 105$ & $8519-8369$ & $6570-6420$ \\
\hline Ua-728 & A 102 & $7190 \pm 110$ & $8069-7919$ & $6120-5970$ \\
\hline Ua-1316 & A 211 & $7390 \pm 105$ & $8336-8222$ & $6387-6110$ \\
\hline Ua-1317 & A 223 & $6465 \pm 105$ & $7439-7197$ & $5490-5248$ \\
\hline Ua-1318 & A 252 & $6155 \pm 100$ & $7150-7035$ & $5230-4940$ \\
\hline Va-1319 & A 289 & $3925 \pm 100$ & $4524-4239$ & $2575-2290$ \\
\hline Va-1320 & A 290 & $2990+105$ & $3349-2999$ & $1400-1050$ \\
\hline Ua-1321 & A $36-36.5$ & $5070 \pm 120$ & $5949-5657$ & $4000-3708$ \\
\hline
\end{tabular}

\footnotetext{
+ Calibrations according to University of Washington Quarternary Isotope Lab Radiocarbon Calibration Program 1987, Rev 1.3 (Pearsson \& Stuiver 1986; Pearsson et al. 1986).
} 
6000 ) and that the ${ }^{14} \mathrm{C}$ dates that do not fall within this interval should be explained away as contaminated or for other reasons unusable. The value of ${ }^{14} \mathrm{C}$ analysis as an archaeological method has, in other words, been reduced to a confirmation of what we already think we know.

In order to get a better general picture of this chronological variation, the results can be roughly summarized by the number of samples per millennium, as in the table below.

At first glance two interpretations of the history of occupation at Tingby appear possible:

\begin{tabular}{|r|r|}
\hline Millennium & $\begin{array}{r}\text { Number of } \\
\text { analyses }\end{array}$ \\
\hline $7000-6000$ & 3 \\
\hline $5999-5000$ & 3 \\
\hline $4999-4000$ & 0 \\
\hline $3999-3000$ & 1 \\
\hline $2999-2000$ & 2 \\
\hline $1999-1000$ & 1 \\
\hline $999-0$ & 0 \\
\hline $0-1000$ & 2 \\
\hline
\end{tabular}

If the 12 samples really are representative of the occupation, they can be interpreted as representing a relatively intensive degree of use of the site during the period 6500-5000 b.c.; no less than half of the dates (as well as the lithic material) are from this period. During the fifth and first millenia b.c. the site apparently was no longer so attractive, but during the remainder of the prehistoric period occupation was fairly constant.

If, however, we choose to draw conclusions only on the basis of a significantly larger number of samples than those discussed above, i.e., if the 12 samples are regarded as unrepresentative, we must be satisfied with pointing out that the area of Tingby was more or less intensively occupied during all prehistoric periods, from 6500 b.c. to A.D. 900 , the period covered by the series of samples. What remains is thus a completely normal chronologically mixed occupation site of the type known by the dozens.

The excavators have, as already stated, chosen to ignore analysis of the validity and reliability of the sources of their data, clinging instead to the contention that the artifacts date the house. The fact that many finds lay within the walls of the house makes the argument non plus ultra. They wonder what happened to the finds that should have been found outside of the house. The same question must reasonably be asked regarding the sheet midden. Why were only scattered remnants left behind outside of the house? In my first article I tried to give an alternative explanation. In this article I try to clarify that explanation. I still believe that this is at least as pertinent as the excavators' interpretation.

In the latest article we're also provided with site plans where the extent and position of the artifacts and features are presented. It can thus be established that the distribution of the lithic material doesn't stop at the walls of the house as was asserted previously. Unfortunately only a distribution map of the finds in the house and the presumed entrance is provided, despite the fact that, according to the text and figure 6(Rajala \& Westergren 1990:10), areas outside the house itself were also excavated. What picture would have been obtained if the distribution map had been extended to the area outside of the house, which was also presumably excavated in one meter squares?

As the most recent article explains (Rajala \& Westergren 1990:16, fig. 9) the distribution of the lithic material was classed into five density classes: $10-30$ artifacts per $\mathrm{m}^{2}, 30-$ $50,50-75,75-100$, and more than 100 artifacts per $\mathrm{m}^{2}$. Only the meter squares in the house and east of it, in the so-called vestibule, are included. Besides questioning where the category 1-9 went, one naturally wonders how the picture would have looked if other divisions had been chosen for the categories, e.g., if regular classes of 25 ( $1-25,26-50$ etc.) or another number of artifacts was chosen and 
also applied to the area outside of the house itself. After all, ca $20 \%$ of the lithic material was found there. The classificatory division which was chosen, as well as the decision to omit the area outside the house, leads to the distinct risk that the distribution picture is skewed. However it is'nt possible to comment on this further as long as no further data is presented; up until now the excavators have been satisfied to report that only "odd finds" (Rajala \& Westergren 1990:14) were found outside of the house.

It is also a little surprising that the coordinate system is set up so that the meter squares correspond completely with the walls of the house. Since normally the coordinate system is lain out on the surface of a site before excavation is begun, does this mean that the postholes were visible before they reached the layer containing the artifacts? In other words, if this layer was cut by the postholes, this suggests the layer existed already before the postholes were dug.

In any case, it can already be established that the meter squares with the most finds (if for the sake of clarity the density classes 1 trough 4 are lumped together) also extend outside the walls of the house to the east and there surround feature 90, a "presumed hearth", now termed an "unspecified feature" (Rajala \& Westergren 1990:22). This, in fact, has an acceptable date, as can be seen in the table above. It is, of course, tempting - despite the missgivings expressed above - to suppose that maybe it is this feature, and not the hearth inside the house, which is associated with the lithic material. In the current case, we are left with two different distributional pictures of the site, one for the lithic material, dating to ca. 6500 B.C., and another for the house itself and the hearth that is spatially associated with it, with a completely different date (Fig. 3). Again, the fact that most of the artifacts were found in the house can be explained by their better preservation under the floor, while thoose outside of the house were spread out over a larger area as the land was cultivated and the sheet midden was disturbed. It is easy to understand that a connection between the artifacts and the house was originally thought to exist, as well as the euphoria evoked by the thought of such a "sensational" find at the moment of excavation. However, it seems incomprehensible that instead of scholarly

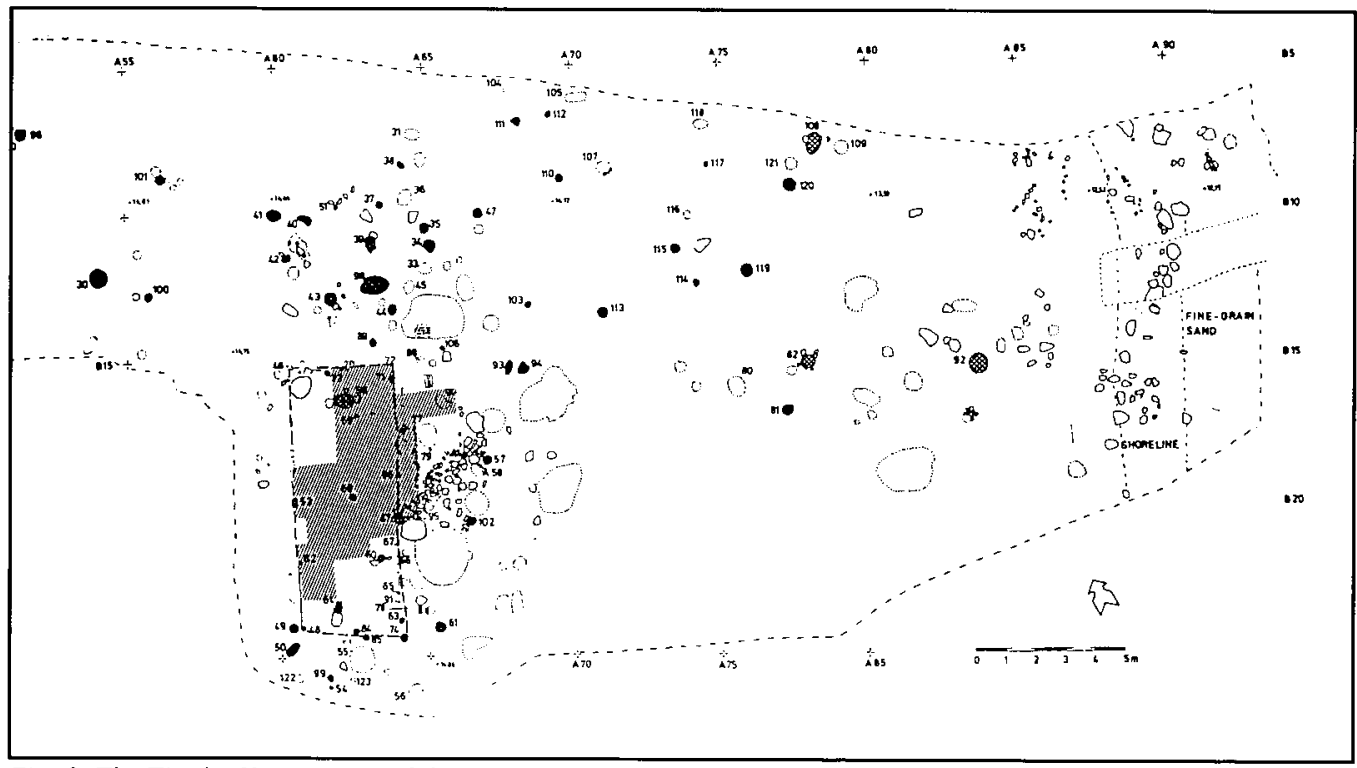

Fig. 3. The Tingby House. Part of the excavated area. After Rajala \& Westergren 1990. 
revision and consideration the excavators chose to crucify themselves on their wild ideas, even though it is clear that the available facts speak against their hypothesis. They have not understood that sensational assertions like the one that have been made are followed by increased demands on the argument for demonstration. Hints and possible interpretations are not enough; all possibilities of other, more "conventional", interpretations must first be rejected in a meaningful way. Rajala and Westergren do not want to discuss such interpretations.

Equally serious is that the sensational immediately spreads to the media, not only to the mass media but also to the popular archaeology magazines which have sprung up. Even after all the publicity the Tingby house received as Scandinavia's oldest house, if it is now shown that the excavators hypotheses obviously aren't supported - at least not as they have been presented thus far - it is unlikely that any retraction will ever be presented in the media. It is difficult to imagine the news that the Tingby house might only have been an ordinary Iron Age house (or for that matter Medieval or Neolithic) - of which we have a good many both on Sweden's west coast and other places - receiving much air play on the television news. One of the consequenses is that both the decision makers and the general public receive the impression of a "simple" science where with small means and minimal demands on the evidence of proof, it is possible to directly turn sensational interpretations into tourist projects, in the worst sence of "cultourism". Other archaeologists" work, with high demands on scientific rigor, risks landing outside the mass media's spotlight and maybe even that of foundations and granting agencies, because they are "only" scholarly. Why throughout the world are so many strange and indistinct remains excavated from a prehistory that is acctually so easily interpreted? The idea of "Scandinavia's oldest house at Tingby" consequently will live on for years as an incontestable fact in the minds of an interested public, until, in the worst case scenario, it is finally cast to the small, edifying collection of archaeological hoaxes, frauds and charlatanisms that exists in the literature, all once prized as sensations and finds which would lead to "history beeing rewritten". We can hope that the continued account of the Tingby excavations will show that the fear of such a scenario is completely unfounded. The loser in the matter would be archaeology as science. There would be no winner.

Translated by Karin L. Jones, University of Michigan, Ann Arbor, USA. 


\section{REFERENCES}

Alin, J, Niklasson, N. \& Thomasson, H. 1934. Stenåldersboplatien pà Sandarna vid Göteborg. Göteborgs Kungl. Vitterhets- och Vetenskapssamhïlles Handlingar. Femte följden. Serie A. Band 3, nr 6. Göteborg. Andersson, S, Nancke-Krogh, S. \& Wigforss, J. (eds.) 1988. Fingstfolk för 8000 ar sedan - om en grupp stenåldersboplatser $i$ Göteborg. Arkeologi i Västsverige 3. Göteborg.

Arkaeologisk håndbog. Leksikon over dansk forhistorie. Köbenhavn 1979.

Artelius, T.\& Lundqvist, L. 1989. Bebyggelse-kronologi. Boplatser från perioden $1800 \mathrm{f} . \mathrm{Kr}$ - 500 e.Kr. i södra Halland. Nya bidrag fill Hallandsäldsta historia, 2. Göteborg 1989.

Hatt, G. 1957. Norre Fjand. An early iron-age village site in Westjutland. Arkacologisk-kunsthistoriske skrifter udgivet af De Kong. Danske Videnskabernes Selskab. Bind 2, no 2. København.

Johansson, L. G. 1989. Var tingbyhuset från järnåldern? (eg. Stenålderns bebyggelse - exemplet Tingby.) Populär arkeologi nr 2, 1989.

Moberg, C-A. 1969. Introduktion till arkeologi. Stockholm.

Pearson, G.W. \& Stuiver, M. 1986. High-precision calibration of the radio carbon time scale. Radiocarbon n. 28 .
Pearsson, G.W, Pilcher, J.R, Baille, M.G, Corbett, D.M. \& Qua, F. 1986. High-precision ${ }^{14} \mathrm{C}$ measurments of irish oaks 10 show the natural ${ }^{1+} \mathrm{C}$ variations from AD 1840-5210 BC. Radiocarbon nr 28.

Rajala, E. \& Westergren, E. 1989. Replik till Johansson 1989. Popular arkeologi nr 2, 1989.

- 1990. Tingby - a mesolithic site with the remains of a house, to the west of Kalmar, in the province of Småland. Meddelanden från Lunds thiversilets historiska musem 1989-1990. New series vol 8 . Lund 1990.

Westergen, E. 1988a. Nordens äldsta hus. Årsboken Kalmar län 1988. Kalmar

- 1988 b. Kalmarbygden fick en "ny" stenålder. Populär arkeologi $11 \% 1,1988$.

- $1988 \mathrm{c}$. Nordens äldsta hus utanför Kalmar. Fynd $m r$ 2, 1988. Göteborg.

- 1988d. Det aildsta kända huset i Norden. Populär arkeologi 11.4 .1988$.

Westergren, E. \& Hansson, A. 1987. Nya rön om stenåldern och bronsåldern i Kalmarbygden. Ärsboken Kalmar län 1987. Kalmar. 
